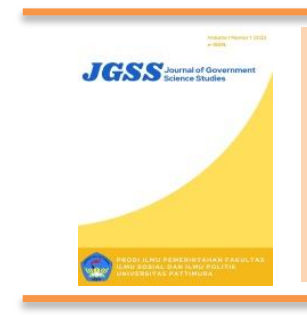

Journal of Government Science Studies

Available online at https://ojs3.unpatti.ac.id/

Vol. 1 No. 1, April 2022, pages: 39-49

e-ISSN: 2827-847X, p-ISSN: 2827-8461

https://doi.org/10.53730

\title{
Kebijakan Pemerintah dalam Penyedian Lahan Pemakaman Umum Masyarakat Kecamatan Sirimau
}

\author{
Regina P. Lainata ${ }^{a}$, Mike J. Rolobessy ${ }^{b}$, Atikah Khairunnisa $^{c}$ \\ Email Corespondensi: reginaprtamaningrum@gmail.com
}

Manuscript submitted: 29-01-2022, Manuscript revised: 31-01-2022, Accepted for publication: 01-02-2022

\footnotetext{
Kata Kunci:

Penataan Pemakaman

1 ;

Penyedian Lahan 2;

Daya Tampung 3.
}

\begin{abstract}
Abstrak: Penataan tempat pemakaman umum (TPU) menjadi persoalan minimnya lahan di Kota Ambon di Kecamatan Sirimau. Persoalan penyedian lahan perkuburan masyarakat yang memiliki daya tampung semakin sempit dan kecil. Kebun Cengkeh mempunyai luas lahan sekitar 5 hektar di bagi menjadi 2 kuburan yaitu 2,5 hektar perkuburan Islam dan 2,5 hektar lagi perkuburan Kristen. Metode penelitian yang digunakan dalam penelitian ini adalah deskriptif kualitatif dengan melakukan wawancara mendalam untuk mengetahui penyedian lahan pemakaman masyarakat. Temuan penelitian dilapangan adalah sebagai berikut (1). lahan tempat pemakaman umum tidak tertata rapi, terlihat semrawut dan sudah tidak layak lagi digunakan sebagai tempat pemakaman umum. (2). Tata wilayah di tempat pemakaman umum yang berada di Kecamatan Sirimau tidak sesuai dengan aturan yang ada (3). Terjadinya tumpang tindih pemakaman dalam satu tempat.
\end{abstract}

\footnotetext{
${ }^{a}$ Universitas Pattimura, Indonesia

${ }^{\mathrm{b}}$ Universitas Pattimura, Indonesia

${ }^{\mathrm{c}}$ Universitas Pattimura, Indonesia
}

Lainata, P. R.,Rolobessy, J.M.,Khairunissa,A. (2022). Kebijakan Pemerintah dalam Penyediaan Lahan Pemakaman Umum Masyarakat Kecamatan Sirimau. Journal of Government Studies Science, 1(1). 


\section{Pendahuluan}

Pertumbuhan penduduk yang semakin meningkat menimbulkan kebutuhan terhadap lahan semakin meningkat pula. Hal ini dapat dilihat pada fenomena semakin banyaknya perumahan yang berada di pinggiran kota. Adanya pembukaan lahan permukiman baru menyebabkan pertumbuhan penduduk baik penduduk baru sebagai pendatang dan penduduk lama yang telah tinggal sebelum adanya permukiman baru. Sehingga menyebabkan peningkatan kebutuhan ruang baik sebagai ruang terbuka hijau maupun ruang terbangun. Sedangkan kenyataannya dalam pembangunan perumahan sebagai permukiman baru terutama skala besar yang seharusnya mempunyai fasilitas lahan pemakaman sebagai salah satu bentuk ruang terbuka hampir setiap perumahan tidak menyediakannya. Menurut Prof. I Made Sandy, seorang ahli geografi, lahan adalah istilah tanah dalam ukuran luas (berdimensi dua), yaitu Ha, m2, tumbak, bahu atau lainnya.

Tanah makam merupakan kebutuhan umat atau orang banyak, yang hakikatnya dilindungi oleh Negara, mengenai pemakaman diatur di dalam Peraturan Pemerintah Nomor 9 Tahun 1987 tentang Penyediaan dan Penggunaan Tanah untuk Keperluan Tempat Pemakaman (selanjutnya disebut PP Nomor 9 Tahun 1987). Menurut Pasal 5 Peraturan Pemerintah NoMOR 9 Tahun 1987 Penyediaan dan Penggunaan Tanah untuk Keperluan Tempat Pemakaman menyatakan bahwa: "Pengelolaan tempat pemakaman umum yang terletak di kota dilakukan oleh Pemerintah Daerah yang bersangkutan berdasarkan Peraturan Pemerintah tingkat II, sedangkan pengelolaan tempat pemakaman bukan umum dilakukan oleh suatu badan atau badan hukum yang bersifat sosial atau keagamaan dengan ijin kepada Pemerintah Daerah tingkat II yang bersangkutan". Pasal 2 ayat (3) Peraturan Pemerintah Nomor 9 Tahun 1987 Penyediaan dan Penggunaan Tanah untuk Keperluan Tempat Pemakaman menyatakan bahwa: "Pembangunan pemakaman tersebut pengelola dilarang melakukan penggunaan tanah yang berlebih-lebihan, dalam arti dilarang pemakaman yang dibuat sedemikian rupa yang mengarah pada pemborosan yang mengakibatkan kerusakan pada sumber daya alam dan terganggunya keseimbangan hidup".

Peraturan Pemerintah Nomor 9 Tahun 1987 Pasal 6 ayat (3) Penyediaan dan Penggunaan Tanah untuk Keperluan Tempat Pemakaman menyatakan: "Tidak dibenarkan adanya pengelolaan pemakaman bukan umum dikelola secara komersial atau pemakaman yang dibisniskan, dijual dengan harga yang tinggi yang diberi fasilitas mewah yang disediakan oleh pengelola pemakaman tersebut". Berbicara mengenai persoalan lahan pemakaman di Kota Ambon, lahannya pemakaman umum di Kota Ambon sudah tergusur dengan pembangunan berbagai proyek-proyek besar, lahan pemakaman di Kota Ambon akan habis, sementara rencana perluasan area pemakaman selalu terhambat oleh masalah pembebasan lahan. Oleh sebab itu, untuk mengatasi hal tersebut, yang berlaku saat ini adalah sistim tumpang dimana 2 (dua) atau lebih jenazah yang umumnya masih memiliki hubungan kerabat menggunakan satu makam yang sama, atau dengan mengambil alih makam yang tidak terurus. Berdasarkan Peraturan Daerah (Perda) Kota Ambon Nomor 20 Tahun 2003 yang direvisi menjadi Perda Nomor 1 Tahun 2015 Tentang Retribusi Pemakaman Dan Pengabuan Mayat, masyarakat wajib membayar lahan milik pemda,apabisa seorang ingin memakamkan jenazah keluarga. Hal ini telah dipenuhi masyarakat. Namun belakangan ini muncul salah satu point dalam Perda Nomor 1 Tahun 2015 yang mewajibkan warga untuk membayar pajak ketika hendak memperbaiki makam keluarga.

Tempat pemakaman umum di Kota Ambon saat ini terdapat 3 lokasi TPU antara lain TPU Benteng dan TPU Kebun Cengkeh untuk warga yang beragama Kristen dan TPU Mangga Dua untuk warga yang beragama Islam. Selain itu juga terdapat TPU yang ada di masing-masing Desa atau Negeri di wilayah Kota Ambon, yang dikelola oleh Pemerintah Desa atau Negeri. Sebagaimana termuat dalam Pasal 5 Ayat (2) Peraturan Pemerintah Republik Indonesia Nomor 9 Tahun 1987 Tentang Penyediaan Penggunaan Tanah Untuk Keperluan Tempat Pemakaman Bahwa "Pengelolaan Tempat Pemakaman Umum di Desa dilakukan oleh Pemerintah Desa berdasarkan Peraturan Daerah Tingkat II yang bersangkutan". Namun tidak semua Desa atau Negeri yang 
memiliki tempat pemakaman umum, lokasi pemakaman biasanya dilakukan pada pekarangan rumah sehingga kelihatan tidak tertata secara baik dan berdampak pada pencemaran lingkungan, ditegaskan oleh Pemerintah Kota (Pemkot) Ambon yang melarang warganya memakamkan jenazah di pekarangan atau halaman rumahnya. Larangan ini telah disosialisasikan kepada masyarakat melalui Lurah dan Kepala Desa, yang disampaikan oleh Kepala Dinas (Kadis) Kebersihan dan Pertamanan Kota Ambon, John Leatomu di Ambon. Tetapi masalah ini perlu dikuatkan dengan Regulasi yang jelas karena sampai saat ini masih belum ada Peraturan Daerah terkait Penataan dan Pengelolaan TPU. Menurut Undang-Undang Tata Ruang Kota kelerengan diatas $15 \%$ itu sudah termasuk dalam kawasan lindung yang artinya sudah tidak di perbolehkan adanya kegiatan apapun. Namun ada beberapa lokasi pemakaman yang sudah sampai pada lokasi lereng lereng gunung dan masih menerima jenazah untuk di kuburkan di tempat tersebut. Pemerintah belum menutup atau melarang lokasi tersebut dalam menerima kuburan baru jika lokasi tersebut sudah full dan tidak ada tempat lagi.

\section{Tabel 1}

Lokasi TPU di Kecamatan Sirimau

\begin{tabular}{|c|c|c|c|}
\hline Nama TPU & Lokasi & Kondisi & Keterangan \\
\hline $\begin{array}{ll}\text { TPU } & \text { Kebun } \\
\text { Cengkeh } & \end{array}$ & Kebun Cengkeh & $\begin{array}{l}\text { Tidak layak, Sudah } \\
\text { melebihi batas yang } \\
\text { tersedia }\end{array}$ & $\begin{array}{lr}\text { Tanah } & \text { milik } \\
\text { pemerintah } & \text { Kota } \\
\text { Ambon } & \\
\end{array}$ \\
\hline Gunung Melintang & Gunung Melintang & $\begin{array}{l}\text { Layak dan masih } \\
\text { mampu } \\
\text { menampung } \\
\text { jenazah }\end{array}$ & Tanah milik pribadi \\
\hline Wara & Wara & $\begin{array}{l}\text { Layak dan masih } \\
\text { mampu } \\
\text { menampung } \\
\text { jenazah }\end{array}$ & Tanah milik pribadi \\
\hline Galala & Galala & $\begin{array}{l}\text { Sudah tidak layak } \\
\text { untuk di jadikan } \\
\text { TPU }\end{array}$ & Tanah milik pribadii \\
\hline
\end{tabular}

Sumber: Analisisi lapangan, 2021

Kecamatan Sirimau terdapat 1 TPU besar yaitu Kebun Cengkeh. TPU tersebut semuanya bisa di katakan sudah tidak layak lagi untuk menampung jenazah karena sudah tidak mencukupi lagi. TPU Kebun Cengkeh mempunyai luas lahan sekitar 5 hektar di bagi menjadi 2 kuburan yaitu 2,5 hektar perkuburan Islam dan 2,5 hektar lagi perkuburan Kristen. Di pekuburan islam sendiri sudah sekitar 2500 lebih kuburan dan jumlah itu tidak terhitung dengan jenazah yang di makamkan secara bertumpuk dengan keluarga. Ada yang satu liang terdiri dari 5 sampai 7 jenazah yang masih satu keluarga. Pekuburan kristen sendiri sudah menampung sekitar 2500 lebih kuburan dan jumlah itu tidak terhitung dengan jumlah jenazah yang di makamkan secara bertumpuk. Sama seperti di pekuburan islam satu liang bisa terdiri dari 3 sampai 4 jenazah yang masih satu keluarga.

\section{Metode Penelitian}

Penelitian deskriftif Menurut Arikunto (1995) adalah penelitian yang dimaksud untuk mengumpulkan informasi mengenai status, yaitu gejala menurut apa adanya pada saat penelitian dilakukan, sedangkan pendekatan kualitatif adalah penelitian yang menghasilkan prosedur

Lainata, P. R.,Rolobessy, J.M.,Khairunissa,A. (2022). Kebijakan Pemerintah dalam Penyediaan Lahan Pemakaman Umum Masyarakat Kecamatan Sirimau. Journal of Government Studies Science, 1(1). 
analisis dan tidak menggunakan prosedur analisis statistik atau cara kuatifikasinya Moleong 2012). Pemilihan jenis penelitian deskriptif dengan pendekatan kualititif yang di gunakan dalam penelitian ini dirasa paling sesuai untuk menjawab focus penelitian dengan mengumpulkan data informasi kemudian di gambarkan dalam sebuah deskrisi atau uraian agar bisa di ta rik kesimpulan. Menurut Lofland and Loflad (dalam Ulum, 2013) ada empat alasan memilih penelitian yang menarik yaitu (1) menarik minat penelitian dan secara nyata berlokasi di suatu tempat, (2) terdapat pengalaman social yang menarik pola tdak tetap, (3) adanya keunikan individu dan jenis setting yang tidak asli serta banyaknya bentuk pngalaman social, dan (4) adanya masalah yang diteliti belum mendapatkan solusi.

Adapun yang menjadi informan penelitian ini adalah : (1). Kepala Seksi Pemakaman Umum Dinas Perumahan Rakyat dan Kawasan Permukiman Kota Ambon. (2). Kepala Seksi Pemerintahan Umum Kecamatan Sirimau. (3). Pengurus Makam. (4). Masyarakat sekitar TPU.

Tabel 2

Daftar Informan

\begin{tabular}{|l|l|c|c|}
\hline No & Nama Informan & Kode Informan & Keterangan \\
\hline 1 & Julianus Hattu, ST & I-1 & Kepala Seksi Pemakaman \\
\hline 2 & $\begin{array}{l}\text { Decky O.S } \\
\text { Sopamena, S.H }\end{array}$ & I-2 & $\begin{array}{c}\text { Kasi Pemerintahan Umum } \\
\text { Kecamatan Sirimau }\end{array}$ \\
\hline 3 & Ibu Christina & I-3 & Warga sekitar TPU Galala \\
\hline 4 & Ibu Munna & I-4 & $\begin{array}{c}\text { Warga sekitar TPU Kebun } \\
\text { Cengkeh }\end{array}$ \\
\hline 5 & Pak Yono & I-5 & $\begin{array}{c}\text { Petugas makam TPU Kebun } \\
\text { Cengkeh }\end{array}$ \\
\hline 6 & Pak Ridholof & I-6 & \begin{tabular}{c} 
Petugas makam TPU Galala \\
\hline
\end{tabular} \\
\hline
\end{tabular}

Sumber: Data Informan Penelitian, 2021

\section{Hasil dan Diskusi}

\section{Ketersediaan Lahan Pemakaman Umum}

Faktanya makam sebagai fasilitas umum cenderung terabaikan keberadaannya. Budiharjo dan Sitio (2015) menegaskan bahwa makam sebagai komponen utama dalam siklus kehidupan kota harus dipertahankan keberadaannya. Berdasarkan SNI 03-1733-2004 tahun 2004 tentang perencanaan perumahan kota, setiap kawasan berpenduduk 120.000 jiwa seharusnya memiliki minimal 1 (satu) ruang terbuka yang berfungsi sebagai pemakaman dengan luas yang tidak di tentukan. Pemerintah harus menyediakannya secara keseluruhan karena sebagian tanggung jawab dapat diserahkan kepada pihak lain (Sadyohutomo, 2008). Pelaksanaan konsep kemitraan kebijakan organisasi menjadi faktor keberhasilan implementasi program organisasi pemerintah ( Tuanaya, Wance, 2021).

Salah satu sarana perkotaan yang sangat penting dan saat ini sedang terancaam keberadaannya di Kota Ambon adalah tempat pemakaman umum. Pemakaman umum merupakan salah satu fasilitas sosial yang berfungsi sebagai tempat pemakaman masyarakat yang meninggal 
dunia. Pemakaman umum juga menjadi fungsi lain seperti RTH, daerah resapan air, dan paru-paru kota. Lahan pemakaman selain digunakan untuk tempat pemakaman, umumnya memiliki sedikit lahan untuk ruang terbangun dan sisanya ditanami berbagai jenis tumbuhan. Paradigma baru administrasi publik muncul dengan merumuskan serangkaian idealism dan praktik terkait penggunaan nilai dan norma tertentu dalam pelaksanaan akuntabilitas pelayanan publik (Herizal, Mukhrijal, Wance, 2020).

Pelayanan pemakaman merupakan salah satu bentuk layanan pemerintah daerah yang sangat penting bagi masyarakat. Sebab kematian merupakan hal yang alami, tidak dapat dipercepat atau di tunda oleh manusia. Selalu dan pasti terjadi setiap saat sehingga pemerintah kota harus dapat menyediakan layanan tersebut terutama dalam penyediaan petak makam yang di perlukan oleh masyarakat. Berdasarkan hasil wawancara yang dilakukan informan tentang peran pemerintah kota ambon dalam penyediaan lahan pemakaman, berikut wawancara peneliti dengan kepala seksi pemakaman umum dinas perumahan rakyat dan kawasan pemukiman Kota Ambon (I1):

"Lahan untuk pemakaman di Kota Ambon terkhusus Kecamatan Sirimau sendiri sudah tidak tersedia atau sudah tidak ada lagi lahan kosong dan luas untuk dijadikan tempat pemakaman baru. Pemerintah saat ini sedang mencari lokasi mana yang cocok untuk tempat pemakaman baru untuk Kecamatan Sirimau. Dinas sedang berusaha mencari lahan kosong untuk tempat pemakaman baru, tetapi di Kecamatan Sirimau sendiri lahan sudah full dengan pemukiman rakyat, dan keadaan geografis Kecamatan Sirimau sendiri tidaklah seutuhnya tanah atau lahan yang tidak miring. Untuk ukuran lahan baru sendiri kita membutuhkan jumlah yang sangat luas jika ada lahan luas mengapa tidak kita gunakan sebagai lahan tempat pemakaman umum baru. Jika lahan baru sudh ada dengan luas yang ada maka kita akan bagi menjadi 2 (dua) lokasi pekuburan sesuai agama yaitu pekuburan agama Islam dan pekuburan agama Kristen sama seperti di Kebun Cengkeh kita akan bagi menjadi dua". (Hasil wawancara 24 agustus 2021) “

Hal senada juga di ungkapkan oleh kepala seksi pemerintahan umum Kecamatan Sirimau (I2) jika pemerintah Kota Ambon dan Kecamatan Sirimau sedang bekerja sama mencari lahan baru yang cocok untuk di gunakan sebagai tempat pemakaman umum baru:

"Saat ini belum ada lahan kosong di Kecamatan Sirimau karena lahan di dalam kota sudah full. Ada lahan kosong tetapi bukan punya Kecamatan Sirimau tapi punya pemerintah Kota Ambon yaitu tempat pemakaman di Hunut Kecamatan Teluk Ambon yang kemarin sempat heboh sebagai kuburan covid-19, padahal itu bukan tempat pemakaman untuk covid-19 itu lahan yang disediakan pemerintah Kota Ambon untuk memakamkan jenazah karena banyak tempat pemakaman umum lainya sudah full. Untuk ukuran lahan sendiri ya kita perlu seluas mungkin ya karena pertumbuhan penduduk di Kecamatan Sirimau pasti bertambah jadi banyak juga warga yang meninggal. Ya tentu kita bakal bagi 2 unit pemakaman berdasarkan agama sama sih kaya di Kebun Cengkeh". (Hasil wawancara 10 september 2021)"

Beberapa masalah yang ada di atas juga di rasakan oleh warga sekitar tempat pemakaman umum di Kecamatan Sirimau, mereka mengeluhkan kurang tersediannya lahan pemakaman untuk menanamkan jenazah baru.

Pemerintah kesulitan untuk mencari daerah yang sesuai untuk tempat pemakaman umum baru. Masyarakat pun mengeluhkan karena lahan pemakaman sudah habis dan hanya bisa berharap dengan sistem tumpang tindih jenazah. Untuk luas sendiri pemerintah tidak menargetkan luas yang harus dicapai jika ada lokasi yang luas untuk membuat tempat pemakaman umum baru maka akan segera di buka. Lokasi pemakaman juga harus jauh dari

Lainata, P. R.,Rolobessy, J.M.,Khairunissa,A. (2022). Kebijakan Pemerintah dalam Penyediaan Lahan Pemakaman Umum Masyarakat Kecamatan Sirimau. Journal of Government Studies Science, 1(1). 
pemukiman penduduk. Pembagian agama pun akan di gunakan dalam membagi lokasi pekuburan yaitu pekuburan agama Islam dan pekuburan agama Kristen. Pembagian lahan berdasarkan agama sudah mendasar dan menjadi suatu norma yang berlaku di Kota Ambon. Meski demikian prinsip dasar bahwa TPU yang di kelola oleh negara seharusnya dapat diakses oleh keberagam ritual dan tradisi agama telah menjadi peraturan perundangan. Dalam pengelolaan tempat pemakaman di Indonesia biasanya digolongkan berdasarkan agama, terutama untuk yang beragama Islam,karena makamnya yang harus mengarah ke arah kiblat seperti jenazah yang sedang di sholatkan,berbeda dengan agama lain seperti Kristen, Budha, Hindu atau kepercayaan lain yang bebas kuburanya mengarah kemana saja. Pengakuan terhadap norma yang di sepakati warga mayoritas tetap dapat dihargai disamping memberi bagian tempat bagi masyarakat minoritas. Dengan demikian, sebuah tempat pekuburan umum semestinya dapat menampung semua agama, sekaligus menghargai norma yang berlaku di tingkat lokal.

Berdasarkan hasil wawancara dengan narasumber di atas terkait indikator ketersediaan lahan pemakaman umum adalah pemerintah Kota Ambon khususnya Dinas Perumahan Rakyat dan Kawasan Pemukiman kesulitan menemukan lahan baru di karenakan lahan yang akan dipakai untuk tempat pemakaman baru sudah tidak ada dan banyak lahan yang sudah alih fungsikan sebagai kawasan pemukiman baru dan kawasan pertokoan. Selain digunakan sebagai kawasan pemukiman dan kawasan pertokoan keadaan geografis atau letak topografis Kecamatan Sirimau sendiri tidak memunginkan untuk dijadikan tempat pemakaman baru tersebut, karena lahan pemakaman harusnya mempunyai daerah yang landai dan tidak ada jurang.

\section{Pemeliharaan Lahan TPU}

Dinas perumahan rakyat dan kawasan pemukiman melakukan suatu pengelolaan yang sesuai oleh peraturan daerah yang mengatur tentang pemakaman. Peraturan yang mengatur tentang retribusi pelayanan pemakaman dan pengabuan mayat di Kota Ambon adalah Peraturan Daerah Kota Ambon Nomor 1 Tahun 2015 tentang Retribusi Pelayanan Pemakaman dan Pengabuan Mayat dan PP No. 9 Tahun 1987 Pasal 2 ayat 3. Infrastuktur metujuk pada sistem fisik yang menyediakan transportasi, pengairan, drainase, bangunan-bangunan gedung dan fasilitas publik yang lain yang dibutuhkan untuk memenuhi kebutuhan dasar manusia dalam lingkup sosial dan ekonomi (Grigg,1988 dalam Kodoatie,2005). Sementara itu adapun pengertian prasarana menurut Jayadinata (1992 dalam Juliawan,2015) prasarana merupakan suatu faktor potensial yang sangat penting dalam menentukan arah dan masa depan perkembangan suatu wilayah, karena pembangunan tidak akan sukses dan berjalandengan baik tanpa dukungan prasarana yang memadai, prasarana kota merupakan fasilitas umum yang menjadi penunjang utama terselenggaranya suatu proses atau kegiatan dalam kota yang pada akhirnya akan menentukan perkembangan kota.

Meski telah ada kebijakan yang mengatur tentang penyelenggaraan pemakaman di Kota Ambon akan tetapi masih kenyataan di lapangan masih banyak di temukan bentuk ketidak sesuaian dengan aturan yang berlaku. Layak tidaknya sebuah kuburan juga menjadi masalah dalam hal ini apakah sebuah kuburan layak di katakan atau mampu menampung jenazah baru. Berdasarkan hasil wawancara yang dilakukan informan tentang peran pemerintah Kota Ambon dalam penyediaan lahan pemakaman, berikut wawancara peneliti dengan kepala seksi pemakaman umum Dinas Perumahan Rakyat dan Kawasan Pemukiman Kota Ambon(I1):

"Makam atau kuburan adalah sebuah tempat yang dibuat untuk menanamkan atau menguburkan jenazah orang yang telah meninggal. Kuburan atau makam ini biasanya terletak di tempat pemakaman.Letak tempat pemakaman harus jauh dari pemukiman penduduk, lokasi topografinya harus bagus. Akses masuk ke lokasi pemakaman haruslah memadai, ukuran kuburan harus seragam agar terlihat tertata rapih dan seragam, harus ada jalan setapak di setiap blok agar memudahkan kita berjalan. Untuk jumlah retribusi sendiri sudah tercantum 
dalam Perda Kota Ambon nomor - 1 tahun 2015 di situ tercantum semua kategori dan tarif yang harus dibayarkan per tahun".(Hasil wawancara 24 Agustus 2021)"

Berbanding terbalik dengan yang ada di lapangan nyatanya tempat pemakaman umum di Kecamatan Sirimau tidak sesuai dengan apa yang pemerintah katakan. Menyangkut hal tersebut peneliti melakukan wawancara dengan petugas pemakaman TPU Kebun Cengkeh (I5):

"Kondisi pemakaman di sini ya sudah tidak teratur lagi, sudah tidak ada jarak antar makam satu dengan yang lainnya. Di sini dimana ada lahan kosong ya kita gunakan biarpun itu di dekat tembok pembatas, pinggiran jurang, pokonya di mana ada tempat kosong ya kita pakai. Bentuk makam di sini juga terlihat tidak seragam dan ya bisa di lihat begini lah". (Hasil wawancara 25 September 2021)."

Berdasarkan hasil wawancara dengan narasumber diatas terkait indikator pemeliharaan lahan tempat pemakaman umum didapati bahwa sejumlah tempat pemakaman umum tidak layak. Sedangkan layak tidaknya tempat pemakaman umum bisa di lihat dari lokasi,letak topografinya,dan bagaimana akses untuk sampai pada lokasi pemakaman tersebut. Lokasi pemakaman haruslah jauh dari rumah penduduk agar tidak terganggu. Ukuran kuburan juga haruslah seragam agar terlihat rapi dan teratur. Adanya jalan setapak di setiap blok untuk memudahkan pejalan kaki berjalan saat akan mengunjungi makam atau pada saat membawa jenazah untuk di makamkan.

\section{Sistem Tumpang Tindih Jenazah}

Sistem tumpang tindih jenazah adalah sistem yang digunakan oleh masyarakat untuk menggabungkan lebih dari satu jenazah dalam satu liang lahat dan masih merupakan anggota keluarga terdekat. Masa pakai lahan makam yang diprediksi hanya mampu bertahan kurang lebih 1 tahun untuk masing-masing TPU dapat di atasi dengan menerapkan dengan menerapkan sistem tumpang tindih, dimana setiap satu makam dapat di isi oleh dua atau lebih jenazah. Adanya penerapan sekali sistem makam yang ada di perkirakan dapat bertahan selama 50 tahun mendatang untuk setiap tempat pemakaman umum. Fungsi prasarana adalah untuk melayani dan mendorong terwujudnya lingkungan permukiman dan lingkungan usaha yang optimal sesuai dengan fungsinya, upaya memperbaiki lingkungan membutuhkan keseimbangan antar tingkat kebutuhan masyarakat (Diwiryo,1996 dalam Juliawan, 2015). berkembang menjadi perencanaan tata ruang; dan yang berkenaan dengan aktivitas hubungan dengan perencanaan pembangunan dalam aspek ekonomi, sosial, kelembagaan, dan ekologi (Tarigan 2005; Sirojuzilam dan Mahalli 2010). Sejalan dengan ini, Dusseldorp dan Staveren (1983) menyatakan bahwa perencanaaan wilayah bersifat intergaratif dan komprehensif. Integrative artinya hubungannya dengan jenis perencanaan yang lain, seperti perencanaan nasional, perencanaan sektoran, dan perencanaan desa.

Tapi hal ini tidak bisa diandalkan karena selain tidak semua badan makam dalam suatu lahan bisa di lakukan tumpang tindih juga menyangkut budaya masyarakat yang sebagian besar menghormati keberadaan makam. Berdasarkan hasil wawancara yang dilakukan informan tentang peran pemerintah Kota Ambon dalam penyediaan lahan pemakaman, berikut wawancara peneliti dengan kepala seksi pemakaman umum Dinas Perumahan Rakyat dan Kawasan Pemukiman Kota Ambon(I1):

"Sistem tumpang tindih bisa di bilang bisa membantu dalam penggunaan lahan pemakaman, karena apa dengan sistem ini kita bisa hemat tempat,dan tidak memiliki dampak yang berarti untuk lokasi tempat pemakaman". (Hasil wawancara 24 Agustus 2021)"

Lainata, P. R.,Rolobessy, J.M.,Khairunissa,A. (2022). Kebijakan Pemerintah dalam Penyediaan Lahan Pemakaman Umum Masyarakat Kecamatan Sirimau. Journal of Government Studies Science, 1(1). 
Beberapa masyrakat menyetujui sistem tumpang tindih ini, karena berbagai alasan yang menguntungkan maka banyak masyrakat. Menyangkut hal tersebut peneliti melakukan wawancara dengan warga sekitar TPU Galala (I3):

"Bagus sistem ini bagus karena bisa mengurangi lahan yang sudah penuh. Sistem ini juga kan tidak merugikan orang lain karna mereka memakai makam keluraga atau sanak saudara mereka". (Hasil wawancara 25 September 2021)"

Berdasarkan hasil wawancara dengan narasumber di atas terkait indikator sistem tumpang tindih adalah dengan melakukan penguburan dengan sistem tumpang tindih adalah sistem menghemat ketersediaan lahan pemakaman. Karena lahan pemakaman semakin terbatas banyak masyarakat yang melakukan pelaksanaan sistem tumpang tindih sebagai solusi untuk mengatasi keterbatasan lahan makam. Tidak ada dampak yang berarti untuk sistem tumpang tindih jenazah, karena dianggap menguntungkan karena tidak perlu mencari tempat baru untuk menguburkan jenazah baru. Syarat yang di pakai jika akan menggabungkan jenazah haruslah jenazah lama harus berumur lebih dari lima tahun atau lebih agar bisa gali kembali dan dijadikan satu dengan jenazah baru.

\section{Tata Wilayah Pemakaman}

Tata ruang adalah wujud struktur ruang dan pola ruang yang disusun secara nasional, regional, dan lokal. Penataan ruang menurut buku pengantar hukum tata ruang (2016) karya Yunus Wahid, merupakan ekspresi geografis yang merupakan cermin lingkup kebijakan yang di buat masyarakat terkait dengan ekonomi, sosial, dan kebudayaan. Perencanaan tata ruang wilayah nasional sudah diatur dalam Peraturan Pemerintah Republik Indonesia Nomor 26 Tahun 2008 tentang rencana tata ruang wilayah nasional. Arahan kebijakan dan strategi pemanfaatan ruang wilayah negara yang dijadikan acuan untuk perencanaan jangka panjang. Selain itu tempat pemakaman harus dilihat sebagai aset, potensi, dan investasi kota jangka panjang sebagai tujuan ekowisata kota dan layanan kremasi yang sehat dan ramah lingkungan, makam bersejarah orangorang terkenal dan ruang spiritual warga kota,yang terbukti mampu mendanai keberlanjutan pemeliharaan dan pengembangan makam, berikut wawancara peneliti dengan kepala seksi pemakaman umum dinas perumahan rakyat dan kawasan pemukiman kota ambon(I1):

"Di lokasi pemakaman dalam konteks tata ruang kota dan pengaturan lokasi pemakaman berdasarkan kedekatannya dengan elemen guna lahan lainnya. Kami akan mengefektifkan fasilitas yang menjadi indikator bahwa suatu TPU dapat di katakan telah efektif dan dapat dijadikan salah satu elemen RTH di perkotaan. Fasilitas yang ada yaitu rumah jaga petugas pemulasaran jenazah, tempat peralatan seperti keranda cangkul dan lain sebagainya. Selain itu juga harus ada jalur pejalan kaki, jalur kendaraan dan tempat parkir harus ada, lampu penerangan, tempat duduk, ruang tunggu. (Hasil wawancara 24 Agustus 2021)"

Berdasarkan hasil wawancara dengan narasumber di atas terkait indikator tata wilayah adalah tata wilayah di tempat pemakaman umum yang berada di Kecamatan Sirimau tidak sesuai dengan aturan yang ada. Kawasan pemakaman umumnya mudah dimasuki secara fisik setiap komponen harus di tata sesuai dengan variabel penataan yang ada pada komponen tersebut seperti luas, bentuk, ukuran, jarak, letak, material pemukaan dan lain lain. Karena dengan fasilitas yang baik maka TPU dapat optimal sebagai salah satu elemen sarana ruang terbuka hijau yang dapat di manfaatkan selain untuk kepentingan pemakaman tetapi juga untuk tempat rekreasi agar menghilangkan kesan mistis yang selama ini masyarakat rasakan. Fasilitas tersebut harus tersedia sebagai upaya dalam pelayanan kepada masyarakat pengguna sarana TPU.

Berdasarkan uraian diatas menunjukan bahwa kurangnya ketersediaan lahan pemakaman di 
Kecamatan Sirimau menjadi salah satu masalah yang cukup besar bagi pemerintah Kota Ambon. Hal ini dapat dilihat dari tanggapan berbagai masyarakat dan Dinas Perumahan Rakyat dan Kawasan Pemukiman Kota Ambon dan juga Kecamatan Sirimau Kota Ambon mengenai empat indikator yang telah di uraikan di atas. Hanya saja masih ada beberapa masalah yang di temukan di lapangan, terkait dengan indikator yang sudah diuraikan di atas.

Sementara itu dari hasil observasi peneliti di lapangan ternyata dapat di ketahui bahwa keadaan pemakaman umum di Kecamatan Sirimau benar-benar sudah tidak layak atau tidak mampu untuk menampung jenazah baru lagi. Lahan yang sudah ada juga tidak seberapa untuk menampung jenazah baru, sekitar 30-40 petak saja lahan yang masih bisa di gunakan untuk menampung jenazah itupun hanya ada di tempat pemakaman umum Kebun Cengkeh khusus agama Kristen. Untuk yang beragama Islam sendiri lahan pemakaman baru sudah sangat susah bahkan sudah tidak bisa menampung jenazah baru lagi.

Pada tempat pemakaman lain pun sama dengan kondisi diatas yaitu sudah penuh atau sudah tidak bisa lagi menampung jenazah baru. Kondisi tempat pemakaman umum di Kecamatan Sirimau bisa di bilang tidak sesuai dengan peraturan meteri dalam negeri nomor 1 tahun 2007 tentang penataan ruang terbuka hijau kawasan perkotaan yaitu letak makamnya tidak teratur, tidak tertata rapi, dan tidak ada jarak antara makam satu dengan yang lain,tidak adanya jalan setapak untuk berjalan dari blok satu ke blok lain. Letak geografis kecamatan sirimau dikatakan tidak memungkinkan untuk membuat tempat pemakaman baru lagi, karena lokasi pemakaman haruslah lahan yang landai dan rata sedangkan wilayah Kecamatan Sirimau sendiri kebanyakan pegunungan,jurang,dan tidak rata. Pegawai pengurus makam pun tidak digaji langsung oleh pemerintah melainkan mengharapkan dari pengunjung makam yang datang ke tempat pemakaman umum tersebut.

\section{Kesimpulan}

Berdasarkan hasil analisa data dan pembahasannya,dapat di tarik kesimpulan bahwa pemerintah Kota Ambon dalam hal ini Dinas Perumahan Rakyat dan Kawasan Pemukiman dan Kecamatan Sirimau Kota Ambon kekurangan dan kesulitan mencari lahan untuk membuka tempat pemakaman umum baru di Kecamatan Sirimau. Lahan yang diperlukan harus luas dan harus jauh dari daerah pemukiman penduduk, dan memiliki akses yang mudah menuju lokasi tempat pemakaman umum baru. Pembagian agama akan di gunakan sebagai pemisah antara pekuburan agama Islam dan pekuburan agama Kristen. Sistem tumpang tindih jenazah menjadi cara alternatif yang di gunakan untuk memakamkan jenazah karena sudah tidak tersedia lahan kosong untuk memakamkan jenazah baru. Hal ini dikatakan demikian karena setelah keempat indikator penelitian ini dioperasionalkan dalam masing-masing sembilan pertanyaan dan ditanggapi oleh keseluruhan informan dengan sebaran jawaban yang di berikan kurang bervariasi dan cenderung memiliki kesamaan maka setelah direkap, dipilah, dan direduksi dapatlah dijelaskan kesimpulannya sebagai berikut:

1. Indikator ketersediaan lahan pemakaman umum dapatlah disimpulkan bahwa berdasarkan hasil wawancara yang disampaikan terkait indikator tersebut dapat ditegaskan bahwa pemerintah Kota Ambon terkhusus Dinas Perumahan Rakyat dan Kawasan Permukiman dan Kecamatan Sirimau Kota Ambon kesulitan mendapatkan lahan baru yang cocok digunakan sebagai lokasi tempat pemakaman baru untuk masyarakat Kecamatan Sirimau. Kecamatan Sirimau adalah kecamatan dengan jumlah penduduk terbanyak di Kota Ambon sehingga banyak pula lahan yang di gunakan sebagai lahan permukiman dan juga lahan pertokoan. Pemerintah tidak menargetkan jumlah luasan lahan untuk lokasi tempat pemakaman yang baru, jika ada lahan yang sesuai maka mereka akan segera membuat tempat pemakaman baru tersebut. Pembagian agama pun masih akan tetap di gunakan untuk menjadi pemisah antara lokasi

Lainata, P. R.,Rolobessy, J.M.,Khairunissa,A. (2022). Kebijakan Pemerintah dalam Penyediaan Lahan Pemakaman Umum Masyarakat Kecamatan Sirimau. Journal of Government Studies Science, 1(1). 
48 ekuburan agama Islam dan lokasi pekuburan agama Kristen. Hal ini sudah menjadi kebiasaan dan bahkan sudah menjadi norma yang berlaku untuk masyarakat Kota Ambon.

2. Indikator pemeliharaan lahan TPU dapatlah disimpulkan bahwa berdasarkan hasil wawancara yang disampaikan terkait indikator tersebut dapat disimpulkan bahwa lahan tempat pemakaman umum yang ada sekarang sangatlah tidak tertata rapi, terlihat semrawut dan sudah tidak layak lagi digunakan sebagai tempat pemakaman umum. Lokasi pemakaman umum di katakan layak jika makam tertata rapi, seragam, memiliki jalan setapak di setiap bloknya untuk memudahkan pejalan kaki menuju makam. Retribusi pelayanan pemakaman dan pengabuan mayat dipungut retribusi sebagai pembayaran jasa pelayanan pemakaman atau penguburan termasuk penggalian dan pengurukan, pembakaran atau pengabuan mayat dan sewa tempat pemakaman yang dimiliki atau oleh pemerintah. Retribusi yang harus dibayarkan haruslah sesuai dengan Perda Kota Ambon nomor 1 tahun 2015, dengan jenis kategori pelayanan yang sudah di atur untuk tarif tersebut.

3. Indikator sistem tumpang tindih jenazah dapat disimpulkan bahwa berdasarkan hasil wawancara yang disampaikan terkait indikator tersebut dapat disimpulkan bahwa sistem tumpang tindih menjadi salah satu cara efektif dalam menanamkan jenazah baru yang sudah tidak kebagian tempat kosong untuk menanamkan jenazah. Sistem tumpang tindih tersebut bisa menampung tiga atau empat jenazah dalam satu liang lahat dengan masing-masing jarak penanaman jenazah diatas lima tahun. Sistem ini hanya bisa dilakukan pada makam yang masih mempunyai hubungan keluarga dekat. Sistem tersebut sangat menguntungkan masyarakat karena tidak perlu mencari lokasi baru untuk menanamkan jenazah baru tersebut.

4. Indikator tata wilayah dapat disimpulkan bahwa berdasarkan hasil wawancara yang disampaikan terkait indikator dapat disimpulkan bahwa tata wilayah di tempat pemakaman umum yang berada di Kecamatan Sirimau tidak sesuai dengan aturan yang ada. Kawasan pemakaman umumnya mudah dimasuki secara fisik setiap komponen harus di tata sesuai dengan variabel penataan yang ada pada komponen tersebut seperti luas, bentuk, ukuran, jarak, letak, material pemukaan dan lain lain. Fasilitas tersebut harus tersedia sebagai upaya dalam pelayanan kepada masyarakat pengguna sarana TPU.

5. Indikator Pemanfaatan Sumber Daya Manusia dapat disimpulkan bahwa berdasarkan hasil wawancara yang disampaikan terkait indikator tersebut dapat disimpulkan bahwa pemerintah akan memanfaatkan warga sekitar lokasi daerah pemakaman baru nanti. Bukan karena apa karena warga sekitarlah lebih mengetahui lokasi tersebut. Dengan menjadikan mereka sebagai pegawai honorer yang di gaji sesuai dengan UMR Kota Ambon akan menambah semangat parai calon pegawai baru. Dengan adanya lokasi pemakaman umum baru juga dapat membuka lapangan pekerjaan baru bagi warga disekitar lokasi tempat pemakaman umum baru tersebut.

\section{Referensi}

Arikunto, Suharsimi. (1995). Manajemen Penelitian, Rineka Cipta, Jakarta.

Diwiryo, Ruslan. (1996). Panel Nasional Ahli Pembangunan Prasarana : Pembangunan prasarana perkotaan di Indonesia. Jakarta. Departemen Pekerjaan Umum.

Darudono, Dodot. (2002). Partisipasi Masyarakat dalam Pelaksanaan Program Pendukung Pembangunan Desa (Sustu Studi di Desa Panggungrejo Kecamatan Panggungrejo Kabupaten Blitar), Unibraw Malang.

Grigg, N. (1988). Infrastructure Engineering and Management, John Wiley \& S

Herizal, H., Mukhrijal, M., \& Wance, M. (2020). Pendekatan akuntabilitas pelayanan publik dalam mengikuti perubahan paradigma baru administrasi publik. Journal of Governance and Social Policy, 1(1). 
Jayadinata, Johara T. (1992). Pembangunan Desa dalam Perencanaan. Bandung: ITB.

Moleong, Lexy J. (2012). Metodologi Penelitian Kualitatif. Bandung : PT Remaja Rosdakarya.

Sadyohutomo. (2008). Manajemen Kota dan Wilayah, Bumi Aksara, Jakarta

Tuanaya, W., \& Wance, M. (2021). Wayame village government partnership pattern in handling COVID 19 in Ambon city. Turkish Journal of Physiotherapy and Rehabilitation, 32(3).

Tarigan, Robinson. (2005). Ekonomi Regional (Teori dan Aplikasi), PT. Bumi Aksara, Cetakan Pertama. Jakarta.

Lainata, P. R.,Rolobessy, J.M.,Khairunissa,A. (2022). Kebijakan Pemerintah dalam Penyediaan Lahan Pemakaman Umum Masyarakat Kecamatan Sirimau. Journal of Government Studies Science, 1(1). 